\title{
REVISION OF A CONCHOSTRACAN FORM FROM THE LA AMARGA FORMATION (LOWER CRETACEOUS), NEUQUÉN BASIN, ARGENTINA
}

\author{
OSCARFLORENCIOGALLEGO \\ Dept. Biología, Paleontología (FACENA - UNNE) y Área Paleontología (CECOAL-CONICET), \\ Casilla de Correo 128, 3400 Corrientes, Argentina.ofgallego@hotmail.com \\ SHEN YAN-BIN \\ Nanjing Institute of Geology and Palaeontology, Chinese Academy of Sciences and State Key Laboratory of \\ Palaeobiology and Stratigraphy, Nanjing 210008, P R China. ybshen@jlonline.com
}

\begin{abstract}
The Cretaceous conchostracan faunas from southern South America are poorly known, only five species were described from Argentina and Uruguay. In contrast, more than twenty seven species were reported from Brazil since the end of the 19th century. In this paper, Euestheria sp. A from the La Amarga Formation (Early Cretaceous - Late Hauterivian to Barremian) in Neuquén Basin is reviewed and assigned to the genus Pseudestherites Chen. This finding represents the sixth record of the genus in the world and the first one outside China. This study increases the Cretaceous conchostracan knowledge from southern South America and brings more evidence about the close relationship among the South American, African and Asiatic conchostracan faunas.
\end{abstract}

Key words: Conchostraca, Lower Cretaceous, Neuquén Basin, Argentina.

\begin{abstract}
RESUMO - As conchostracofaunas cretáceas do extremo sul da América do Sul são pouco conhecidas. Somente cinco espécies foram descritas para a Argentina e Uruguai. Entretanto, as faunas do Brasil são conhecidas desde o fim do século XIX, tendo sido descritas mais de 27 espécies. Eustheria sp. proveniente da Formação La Amarga (Cretáceo Inferior - Hauteriviano superior a Barremiano) da bacia Neuquina é redescrita neste trabalho e atribuída ao gênero Pseudestherites Chen. Este achado representa o sexto registro do gênero em nível mundial e primeiro fora da China. Este estudo aumenta o conhecimento dos conchostráceos cretáceos sulamericanos, aportando novas evidências sobre a estreita relação existente entre as faunas sul-americanas e asiáticas.
\end{abstract}

Palavras-chave: Conchostraca, Cretácico Inferior, bacia de Neuquén, Argentina.

\section{INTRODUCTION}

The Cretaceous conchostracan faunas from southern South America are poorly known. At the moment, only five species were described from Argentina and Uruguay. Euestheria sp. A (Musacchio, 1970) from the La Amarga Formation (Lower Cretaceous, Argentina) in Neuquén province is redescribed here as Pseudestherites musacchioi sp. nov. Cyzicus? codoensis Cardoso (in Chiappe et al., 1998) from the Lagarcito Formation (Lower Cretaceous, San Luis province) is a new species of the genus Dendrostracus Chen and Hudson (Polygraptidae), after the revision of additional material from the Lagarcito Formation from San Juan province (Ballent et al., 2002; Prámparo et al., 2003). In Uruguay, Gallego et al.(1999) described two new species from the Lower Cretaceous, Palaeolimnadiopsis hectori (Palaeolimnadiopseidae) and Tenuestheria canelonesensis
(Euestheriidae) from the Castellanos Formation (Santa Lucía Basin, south Uruguay). Otherwise, Shen et al. (2004) reviewed Migransia ferrandoi (Herbst) (Fushunograptidae) from the Tacuarembó Formation, Upper Jurassic to ?Lower Cretaceous, of Uruguay.

In contrast, more than twenty seven species had been described in Brazil by different authors (see Tasch, 1987; Carvalho, 1993; Rohn \& Cavalheiro, 1996) since the end of the 19th century.

In this paper, the species Euestheria sp. A (Musacchio, 1970) is redescribed based on the study of the original materials using scanning electron microscope (SEM), which provide new evidence of its taxonomic assignment. This species previously assigned to Lioestheriidae (Lioestheriinae) by Musacchio (1970) is now referred to the genus Pseudestherites (Antronestheriidae, Chen \& Hudson, 1991) as a new species. 
According to Musacchio (1970), the fossil samples came from Picún Leufú and Cerro China Muerta localities, but at the moment in the repository there are only five samples (MLP 11354-11357a-b, cited in Musacchio, 1970) that certainly came from Cerro China Muerta locality (level 27 of the profile from Musacchio 1971a, b). Probably, the samples from the level 38 from Cerro China Muerta and levels $4 \mathrm{~b}$ and 9 from the Picún Leufú profile (Musacchio, 1971a, b) are missing, because all of these materials were never finally deposited in this repository.

The studied samples are housed in the Departamento Paleontología Invertebrados del Museo de Ciencias Naturales de La Plata (Argentina) prefixed by MLP. The SEM samples are housed in the Paleozoological Collection of the Facultad de Ciencias Exactas y Naturales y Agrimensura, Universidad Nacional del Nordeste (Corrientes, Argentina) prefixed by PZ-CTES.

\section{GEOLOGICAL SETTING AND DEPOSITIONAL ENVIRONMENT}

The conchostracans samples came (sensu Musacchio, 1970) from two localities: in "Picún Leufú" area, next to Picún
Leufú River, and "Cerro China Muerta" type locality of the La Amarga Formation, Neuquén province (Southeastern border of the Neuquén Basin) Argentina (Figure 1). Both belong to the La Amarga Formation, dated as Early Cretaceous (Late Hauterivian - Barremian) by Musacchio (1989). The Barremian stage was dated by the presence of the charophytes Atopochara trivolvis triquetra Grambast, Triclypella patagonica Musacchio and Mesochara cf. stipitata Wang, and the ostracods Cypridea (Ulwellia) australis Musacchio, C. (U.) subcuadrata Musacchio, $C$. (U.) modestissima Musacchio and Dryelba picunleufensis Musacchio. The possible Hauterivian age was supported by local stratigraphical relations. The non-marine levels belonging to the La Amarga Formation are intertongued between marine sediments of the uppermost Agrio Formation (Musacchio, 1989). At the Picún Leufú locality, the La Amarga Formation is mainly composed of lacustrine gray and grayish-yellow marls including scarse limestones, variegated mudstones and siltstones; it overlies transitionally the Agrio Formation (Musacchio, 1989). Leanza \& Hugo (1997) mentioned that La Amarga Formation unconformably overlies the transitional levels of the Agrio Formation. At the Cerro China Muerta locality, the lower

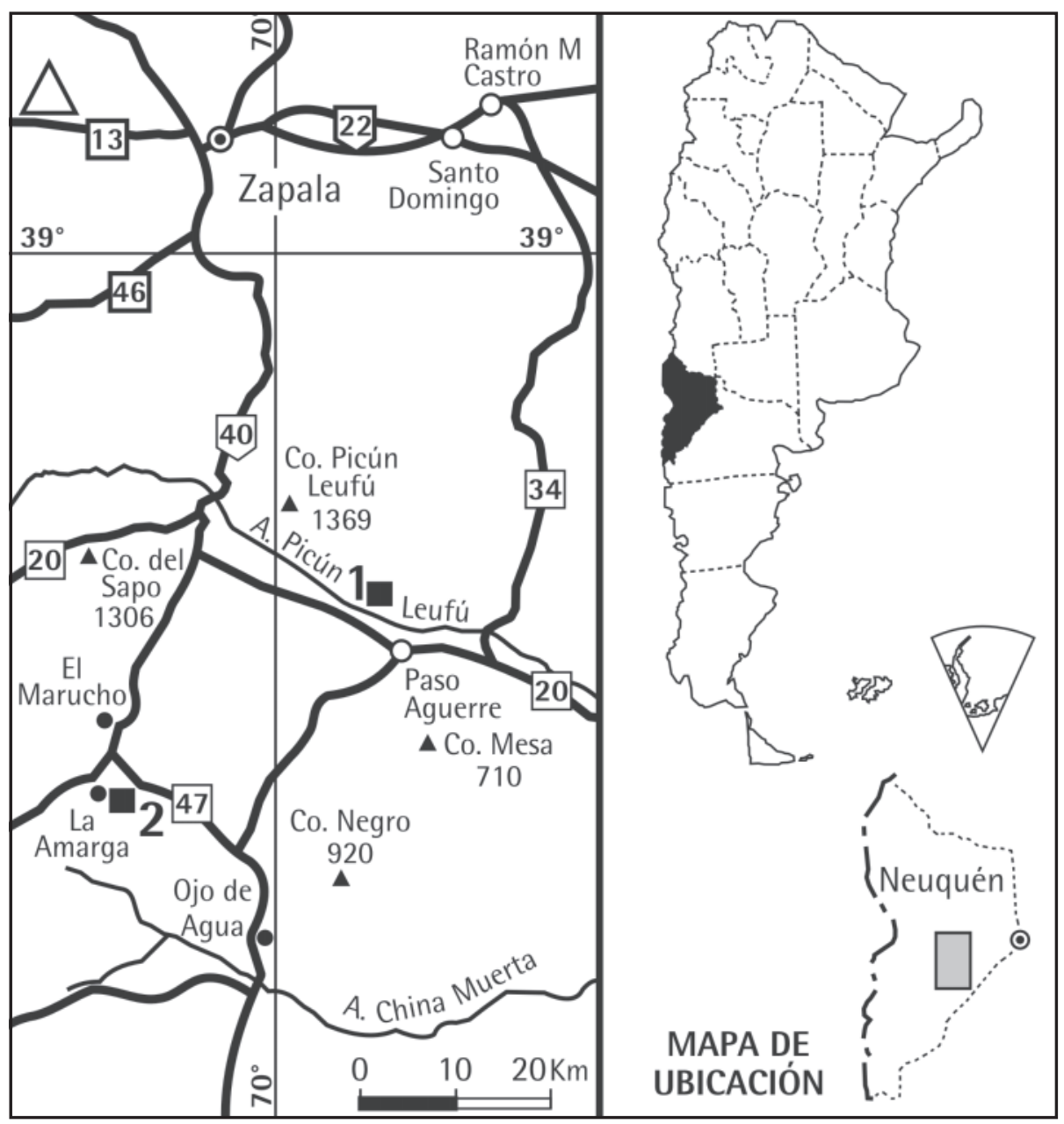

Figure 1. Location map of the fossiliferous localities of the La Amarga Formation, Neuquén Province, Argentina. 1. "Picún Leufú, 2. "Cerro China Muerta" (modified from Prámparo \& Volkheimer, 2002, and Musacchio, 1971a). 
part of the profile of the La Amarga Formation includes continental sandstones and conglomerates, and upwards many limestone levels, also of continental origin (Musacchio, 1989) (Figure 2). Leanza \& Hugo (1995) divided the La Amarga Formation into three members: Puesto Antigual (that provides remains of the sauropod dinosaur Amargasaurus cazaui Salgado and Bonaparte), Bañados de Caichigüe (that contains abundant fossils, such as conchostracans, ostracods, charophytes, pollen and megaspores) and Piedra Parada members. In Leanza \& Hugo (1997), a complete stratigraphical sketch of this area is presented.

Musacchio (1971b) mentioned that the La Amarga Formation could be of continental environmental sediments based on the presence of ostracod Cypridea and other palaeontological evidence (such as plants Equisetites sp. and ostracod "Gomphocythere" neuquenensis Musacchio).

Di Paola (1969) suggested that the diagenetic association "zeolite-clays" that characterizes the sedimentary association from Cerro China Muerta, indicates warm climate conditions with a progressive dryness for the Cerro China Muerta area. According with this conclusion we observed the presence of thin pyrite layer covering the carapace of all conchostracan specimens that suggested an environment with anoxic conditions (high $\mathrm{pH}$ and cationic contents and restricted water circulation).

Prámparo \& Volkheimer (2002) studied the palynological content of an outcropping section of the middle member (Bañados de Caichigüe Member) of the La Amarga Formation located $7 \mathrm{~km}$ east from La Amarga locality. They concluded that, based on the abundance of colonial Chlorococcales (Scenedesmus dominant), mainly large cenobia (24 to 32 cells), a lacustrine environment with a high nutrient content (eutrophic conditions) could be suggested for the studied formation.

The enviromental conditions mentioned above are coincident with the low number of the specimens observed in the studied samples.

\section{SYSTEMATIC DESCRIPTION}

\section{Order CONCHOSTRACA Sars, 1867}

Suborder SPINICAUDATA Linder, 1945

Superfamily EOSESTHERIOIDEA Zhang and Chen

Family ANTRONESTHERIIDAE Chen and Hudson, 1991

Genus Pseudestherites Chen (in Zhang et al., 1976)

Type species. Pseudestherites qinghemenensis Chen (in Zhang et al., 1976); Lower Cretaceous Shahai Formation, Qinghemen, Fuxin city, Liaoning province, China.

\section{Pseudestherites musacchioi sp. nov.} (Figures 3A-D, 4, 5)

1970, Euestheria sp. A, Musacchio, p. 315, Lám. II, Fig. 10.

Etymology. Dedicated to Dr. Eduardo Musacchio for his great
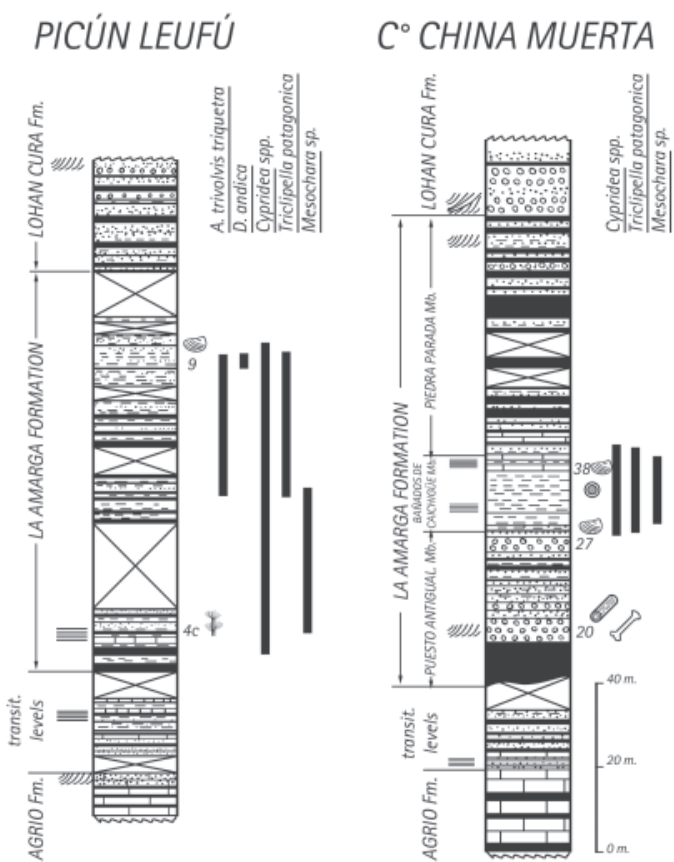

REFERENCES

\begin{tabular}{|c|c|c|}
\hline 몀웜 Conglomerate & 8 & Conchostracans \\
\hline 凅 Sandstone & 0 & Petrified woods \\
\hline Claystone & 8 & Tetrapod bones \\
\hline 圆 Marls & (2) & Palynomorph \\
\hline 回 Limestone & k & Equisetites sp. \\
\hline $\begin{array}{l}\text { D Crossbedding } \\
\text { 目 Laminated }\end{array}$ & 4 & Fossiliferous levels \\
\hline
\end{tabular}

Figure 2. Stratigraphic section of the La Amarga Formation, showing the conchostracan levels and other fossiliferous horizons (modified from Musacchio, 1971a, 1989 and Prámparo \& Volkheimer, 2002).

contribution to the micropaleontology of the JurassicCretaceous continental sediments from Argentina.

Type locality. Cerro China Muerta, Neuquén Province, Argentina.

Holotype. MLP 11354. Dimensions (in mm): $\mathrm{L}=8.2 ; \mathrm{H}=4.6$

Paratypes. MLP 11355A, 11356, 11357a-b, PZ-CTES 7294; 10 complete specimens and 19 fragmentary ones.

Stratigraphic position. La Amarga Formation (probably Bañados de Caichigüe Member), level 27 of Musacchio (1971a).

Age. Early Cretaceous (Late Hauterivian - Barremian)

Diagnosis. Carapace valve elliptical to subtriangular? in outline, moderate in size, straight and long dorsal margin. Subterminal umbo not rising above the dorsal margin. Broad growth bands ornamented with minute punctuated or cavernous sculpture, fossae subcircular to elliptical mostly separated by a smooth surface, dimensions ranging from 0,04 to $0,006 \mathrm{~mm}$, dorsally decreased in size. Last few growth bands ornamented with oblique radial anastomose striae, inclined posteriorly.

Description. Carapace valve elliptical to subtriangular? in outline, telliniform, moderate in size, $3.3-8.9 \mathrm{~mm}$ in length and $2.6-5.1$ $\mathrm{mm}$ in height, straight and long dorsal margin (2/3 of length), 
slopping backward (posteriorly), posterior margin a little more convex and longer than the anterior one. Umbo inset subterminally and not rising above the dorsal margin. Convex umbonal region in younger forms (3.3 long, $2.6 \mathrm{~mm}$ high), with smooth small area. Highest in the medium-anterior region. Ventral margin slightly convex. 13-22 growth lines generally spaced. Broad and convex growth bands, apparently smooth. Growth bands ornamented with minute punctuated or cavernous sculpture (in external mould as pits or small nodes) in the ventral half of each growth band, dorsal half smooth or punctuated. Fossae subcircular (in the dorsal region of the growth band) to transversally elliptical (ventrally), cavities generally separated by a smooth and broad surface around each one, fossae dimensions ranging from 0,006 to $0,04 \mathrm{~mm}$, dorsally decreased in size in each growth band. General view suggests strong and sinuous meshes. Last five or six growth bands with oblique radial anastomose striae, posteriorly inclined probably due to the inclination and lengthening of the cavities.
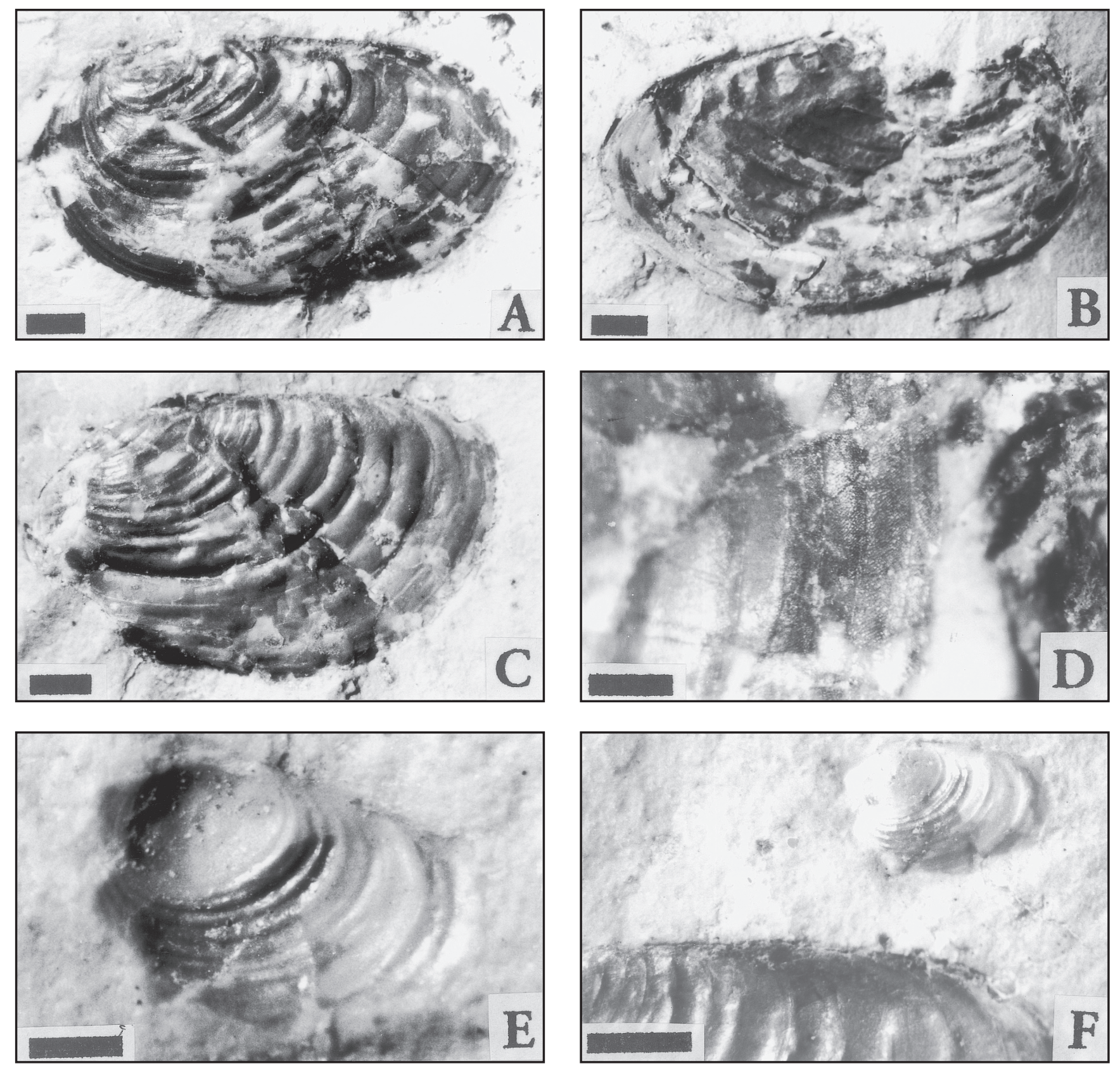

Figure 3. A-D. Pseudestherites musacchioi sp. nov. A. Holotype, MLP 11354, external mould of left valve with elliptical outline, scale bar= $1 \mathrm{~mm}$. B. Paratype, MLP 11356, external mould of right valve with elliptical outline, scale bar = $1 \mathrm{~mm}$. C. Paratype, MLP 11355A, external mould of left valve with oval outline, scale bar $=1 \mathrm{~mm}$. D. Holotype, MLP 11354, ventral detail of a valve showing the oblique radial anastomose striated ornamentation, scale bar $=0.5 \mathrm{~mm}$ E-F. Estheriina ? sp. (or Palaeolimnadia ? sp.), MLP 11355B, E external mould of left valve with convex ovate outline and smooth umbonal region, scale bar $=0.5 \mathrm{~mm}$ and $\mathbf{F}$ same specimen compared with $P$ seudestherites musacchioi sp. nov., MLP 11355A, scale bar $=1 \mathrm{~mm}$. 

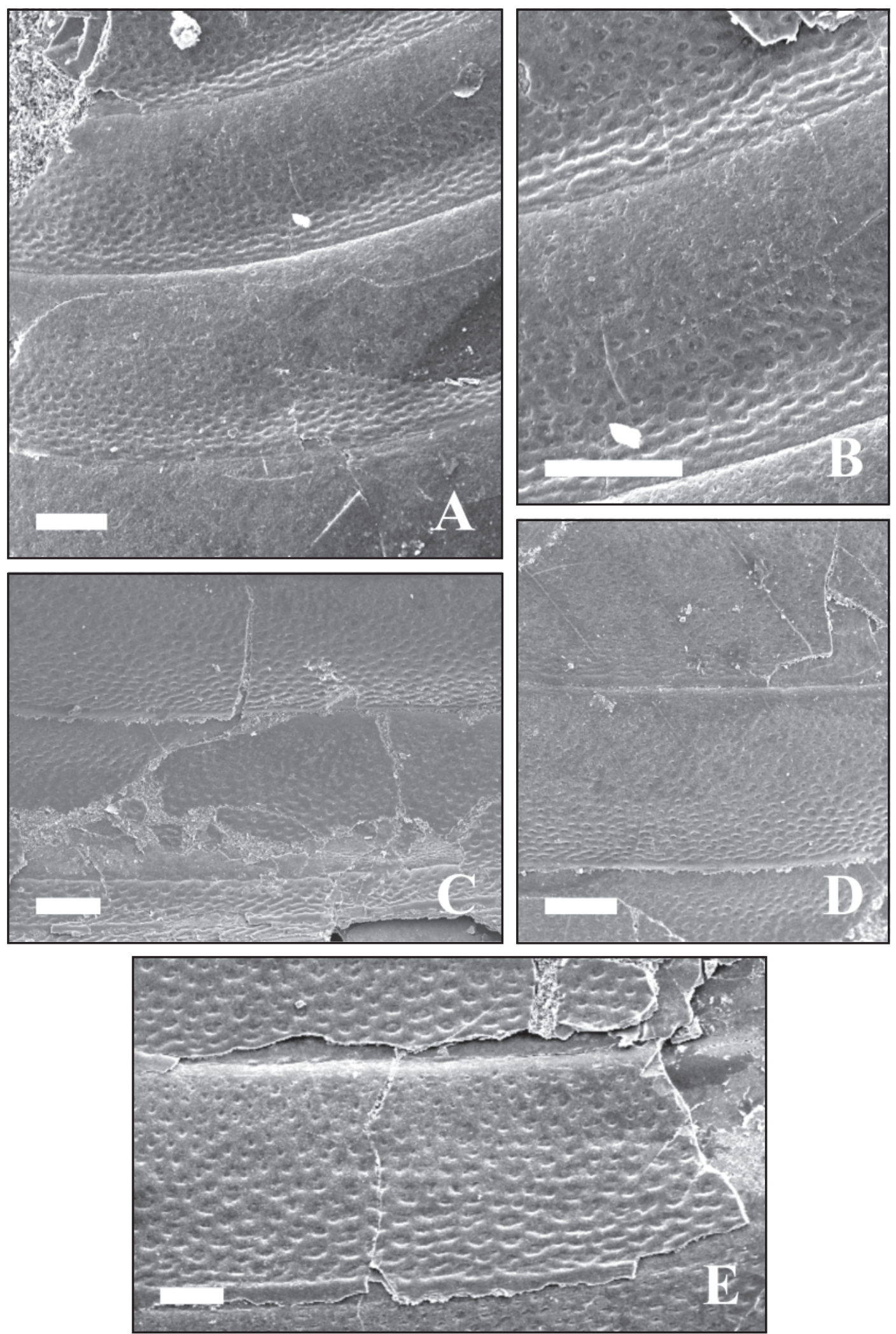

Figure 4. Pseudestherites musacchioi sp. nov., paratype, PZ-CTES 7294 (A-B from Fig. 3A/ MLP 11354, C-D from Fig. 3B/ MLP 11356, and E from Fig. 3C/ MLP 11355), A. Middle-dorsal detail of a valve, showing cavernous ornamentation on the growth bands, weak at the upper part, scale bar $=0,05 \mathrm{~mm}$. B. Middle-dorsal detail showing the ornamentation changed downward with larger size from subcircular to elliptical cavities, scale bar $=0,05$. C. Ventral detail showing the transition between the elliptical cavities to oblique radial anastomose striae (as strong meshes), scale bar = 0,1 mm. D. Middle-posterior detail of a valve, showing the transition between small elliptical cavities to punctuated ornamentation upward, scale bar $=0,1 \mathrm{~mm}$. E. Middle-anterior detail of a valve showing elliptical cavities changed into punctuated ornamentation upward, scale bar $=0,05 \mathrm{~mm}$. 

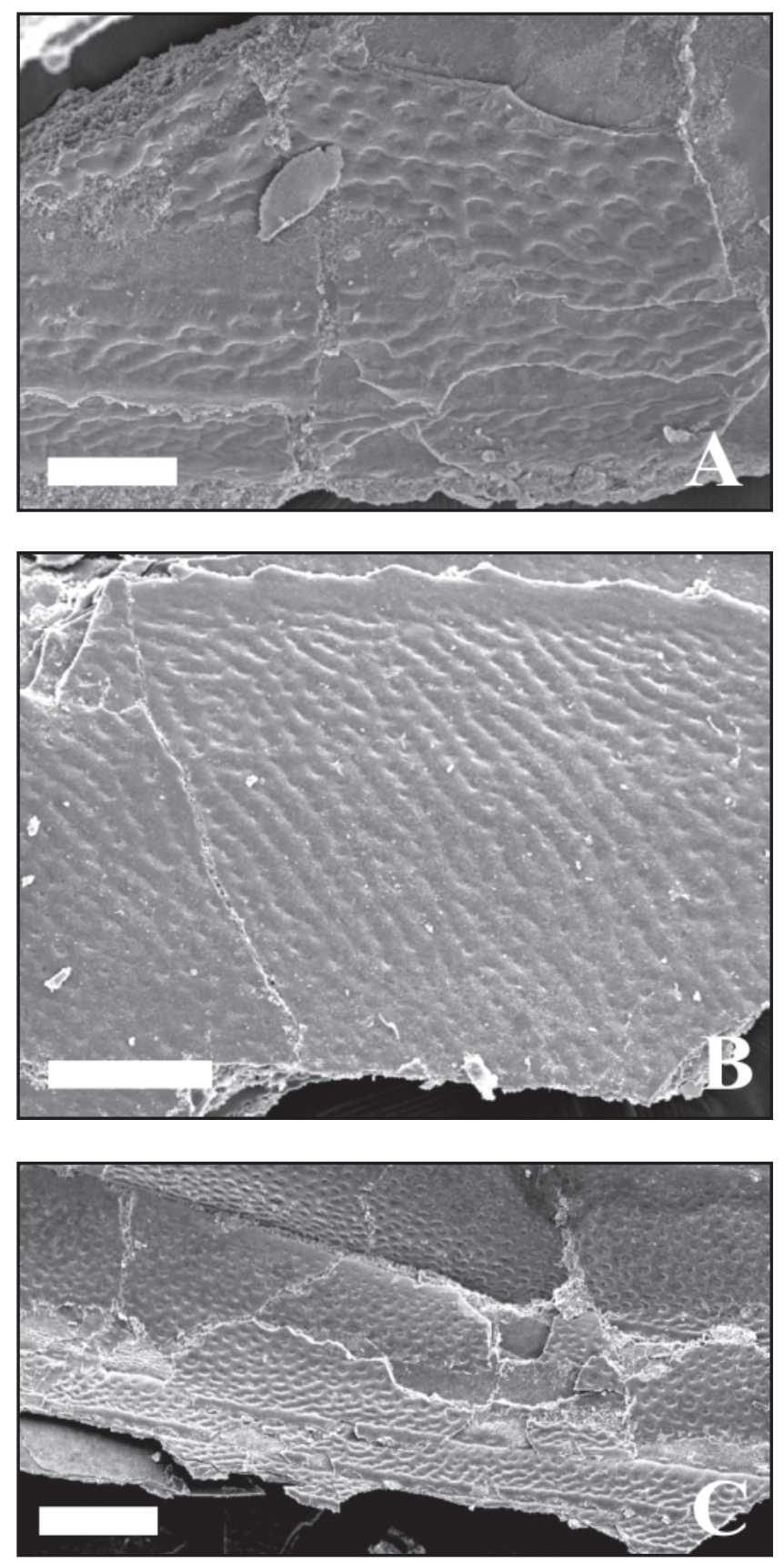

Figure 5. Pseudestherites musacchioi sp. nov., paratype, PZCTES 7294 (A from MLP 11357a, B from Fig. 3A/ MLP 11354, and C from Fig. 3B/ MLP 11356). A-C. Three different aspects of ornamentation on the ventral part of a valve, $\mathbf{A}$ and $\mathbf{C}$ showing ornamentation changing from subcircular or elliptical cavities to oblique radial anastomose striae (as strong meshes), scale bar = $0,1 \mathrm{~mm}$; $\mathbf{B}$, ventral broad growth band with oblique radial anastomose striae, posteriorly inclined, scale bar $=0,05 \mathrm{~mm}$.

Remarks. This is the first record of the genus Pseudestherites Chen outside China, but there is a second form, still unpublished, from the Lagarcito Formation (Albian), Argentina (Prámparo et al., in press). The latter differs from P. musacchioi sp. nov. in its ovate outline, subcentral umbo, equal anterior and posterior height and growth bands ornamented only by small ovate cavities. Both forms are quite similar in dimensions and form of the cavities that decrease in size upward in each growth bands.

In China there are five species of the genus Pseudestherites, that were found in five localities: P. qinghemenensis Chen from the Lower Cretaceous (Hauterivian) Sahai Formation, western Liaoning province (Zhang et al., 1976) and Xiagou Formation, Hexi Corridor, Gansu province (Shen et al., 1982, pl. 18, fig. 11); P. elliptica Dong from the Lower Cretaceous Hengtongshan Formation, southern Jilin province (Dong, 1988); P. jianchangensis $\mathrm{W}$. Wang from the Lower Cretaceous Sahai Formation, Jianchang, Liaoning province (Wang, 1987, pl. 22, figs. 5-12); P. zhangwuensis $\mathrm{W}$. Wang (Wang, 1989, p. 307, pl.1, fig. 3; pl.2, fig. 1) and $P$. leijiaensis W. Wang (Wang, 1989, p. 307-308, pl. 2, fig. 2) from the Lower Cretaceous Sahai Formation, Zhangwu, Liaoning province (NE China).

The new species is quite similar to the type species Pseudestherites qinghemenensis Chen (in Zhang et al., 1976, $\mathrm{p}$. 152, pl. 39, figs. 7-9) in its cavernous sculpture, but the latter shows subquadrate shape, umbo rising above the dorsal margin and the cavernous ornamentation in the dorsal region of the growth band not changed into transversally elliptical in the ventral region. The present species approaches to Pseudestherites elliptica (Dong, 1988, pl. 1, figs.1, 2) in the elliptical outline and ornamentation with radial striae in the postero-ventral region of the valve. But differs from the latter in its ornamental change on the same growth bands that is also distinguishing from Pseudestherites jianchangensis, Pseudestherites zhangwuensis and Pseudestherites leijiaensis.

The new species shows similarities to Tenuestheria canelonesensis Gallego from the Lower Cretaceous (Albian) of Uruguay in outline, straight dorsal margin, subterminal umbo and $\mathrm{H} / \mathrm{L}$ ratio. The latter differs from the present species in the areolar ornamentation, meshes of $0.02 \mathrm{~mm}$ diameter, medium height and clearly different anterior and posterior margins.

It is also compared with other Lower Cretaceous species, "Pseudestheria" abaetensis (Cardoso, 1971) from the Areado Formation in Brazil and Cyzicus (Euestheria) anomala (Jones) Tasch (1987) from Uitenhage Series in South Africa. Both forms share with the present species similar outline, comparative characteristics between anterior and posterior margins, dimensions (with "P." abaetensis) and the location of the umbo, which is not rising above dorsal margin. They differ in the larger length of the dorsal margin (hingeline), abruptly joined with the posterior one, highest at the middle region, minor $\mathrm{H} / \mathrm{L}$ ratio and growth bands with areolar or minute granular ornamentation. In other hand, due to their close similarities, probably "P." abaetensis Cardoso is a synonymous of $C$. (E.) anomala Jones.

Cyzicus (Euestheria) lefranci (Tasch, 1987) from the Upper Cretaceous of Algeria (Africa) shares elliptical outline, straight dorsal margin, posteriorly inclined, joined slightly with the posterior margin and spacing growth bands. But it differs from the present species in subovate specimens, terminal umbo (subterminal in ovate forms), larger $\mathrm{H} / \mathrm{L}$ ratio, smaller size and 
growth bands ornamented with fine reticulate pattern. This form may preserve partly soft parts, such as claspers and digestive tuber (p. 155, pl. 3, fig. 4).

\section{CONCLUDING REMARKS}

This finding represents the sixth record of the genus Pseudestherites in the world and the first one outside China. This study increases the Cretaceous conchostracans knowledge from southern South America and brings more evidence about the close relationship among the South American, African and Asiatic conchostracan faunas (Shen et al., 2004).

Additionally, we found a probable specimen of the genus Estheriina sp. (may be Palaeolimnadia) associated with Pseudestherites musacchioi sp. nov. (see Figure 3E-F). This genus has large record in the Cretaceous sediments of South America, Brazil and Argentina (Lagarcito Formation, Lower Cretaceous; Prámparo et al., 2003).

\section{ACKNOWLEDGEMENTS}

The authors are grateful to Alberto Riccardi and Sara Ballent (Museo de La Plata) for permitting the study of the specimens, to Eduardo Musacchio for his assistance with important bibliography and to Cristina Salgado and Carolina Peichotto (Universidad Nacional del Nordeste) for their assistance with SEM. We thank also Ramón Z. Rodríguez for his work in the photographic laboratory, Gustavo Barrios for his work with digital figures, and María Florencia Treviño for producing the figures. To Mercedes Prámparo and Nora Cabaleri for their interesting comments and suggestions on the manuscript. The authors thanks two anonymous referees for helpfull comments and suggestions. This study was partially supported by the National Nature Science Foundation of China (Grant 40072002) and State Key Laboratory of Paleobiology and Stratigraphy (023101) to Shen Yan-Bin. Thanks also to the Consejo Nacional de Investigaciones Científica y Técnicas (CONICET) for the postdoctoral felowship to OFG, and the Universidad Nacional del Nordeste.

\section{REFERENCES}

Ballent, S.; Gallego, O.F.; Milana, J.P. \& Prámparo, M. 2002. Conchóstracos y ostrácodos en la Formación Lagarcito (Cretácico Inferior alto), Sierra de las Guayaguas, San Juan, Argentina. In: CONGRESO ARGENTINO DE PALEONTOLOGÍA Y BIOESTRATIGRAFÍA, 8, 2002. Resúmenes, Corrientes, UNNE-FACENA, p. 92.

Cardoso, R.N. 1971. Contribução ao estudo da Formação Areado: estratigrafia e descrição dos filópodos fósseis. Arquivos do Museu de História Natural, UFMG, 1:8-47.

Carvalho, I.S. 1993. Os Conchostráceos Fósseis das Bacias Interiores do Nordeste do Brasil. Programa de Pós-graduação em Geologia, Universidade Federal do Rio de Janeiro, Tese de Doutoramento, 319 p.

Chen, P.J. \& Hudson, J.D. 1991. The conchostracan fauna of the Great Estuarine Group, Middle Jurassic, Scotland. Palaeontology, 15(3):515-545.
Chiappe, L.; Rivarola, D.; Cione, A.; Frenegal-Martinez, M.; Sozzi, H.; Buatois, L.; Gallego, O.; Laza, J.; Romero, E.; Lopez Arbarello, A.; Buscalioni, A.; Marsicano, C.; Adamonis, S.; Ortega, F.; Mcgeehe, S. \& Di Iorio, O. 1998. Biotic association and paleoenvironmental reconstruction of the "Loma del Pterodaustro" fossil site (Lagarcito Formation, Early Cretaceous, San Luis, Argentina). Geobios, 31(3):349-369.

Di Paola, E.C. 1969. Procesos diagenéticos en sedimentitas de la República Argentina: Parte I: Formaciones Pichi Picún Leufú, Ortiz, Limay, Bajada Colorada (Provincias de Neuquén y Río Negro). Revista de la Asociación Geológica Argentina, 24(3):199-210.

Dong, J. 1988. A study of fossil conchostracans from Sankeyushu section of Tonghua, Jilin. Acta Palaeontologica Sinica, 27(6):722-728.

Gallego, O.F.; Campos, C.C. \& Veroslavsky, G. 1999. Conchóstracos de la Formación Castellanos (Cretácico Inferior) de Uruguay (Cuenca de Santa Lucía). In: SIMPÓSIO SOBRE O CRETÁCEO DO BRASIL, 5, 1999. Boletim, Rio Claro, UNESP, p. 181-188.

Leanza, H.A. \& Hugo, C.A. 1995. Revisión estratigráfica del Cretácico Inferior continental en el ámbito sudoriental de la Cuenca Neuquina. Revista de la Asociación Geológica Argentina, 50(1-4):30-32.

Leanza, H.A. \& Hugo, C.A. 1997. Hoja Geológica 3969-III-Picún Leufú, Provincias de Neuquén y Río Negro. Instituto de Geología y Recursos Naturales. SEGEMAR, 135 p. (Boletin 218).

Musacchio, E.A. 1970. Ostrácodos de las Superfamilias Cytheracea y Darwinulacea de la Formación La Amarga (Cretácico Inferior) en la Provincia de Neuquén, República Argentina. Ameghiniana, 7(4):301-316.

Musacchio, E.A. 1971a. Charophytas de la Formación La Amarga (Cretácico Inferior) Provincia de Neuquen, Argentina. Revista del Museo de La Plata, Nueva Serie 6, Paleontología, 37:19-38.

Musacchio, E.A. 1971b. Hallazgo del género Cypridea (Ostracoda) en Argentina y consideraciones estratigráficas sobre la Formación La Amarga (Cretácico Inferior) en la Prov. de Neuquen. Ameghiniana, 8 (2):105-125.

Musacchio, E. A. 1989. Biostratigraphy of the non-marine Cretaceous of Argentina based on calcareous microfossils. In: J. Wiedmann (ed.) Cretaceous of the Western Tethys, E. Schweizerbart'sche Verlagsbuchhandlung (Nägele u. Obermiller), p. 811-850.

Prámparo, M.B. \& Volkheimer, W. 2002. Nuevos hallazgos de palinomorfos en la Formación La Amarga, Miembro Bañados de Caichigüe, cuenca Neuquina sudoriental, Argentina. Ameghiniana, 39(4):395-404

Prámparo, B.; Milana, J.P.; Ballent, S. \& Gallego, O.F. 2003. Integrated palynologic and palaeontologic studies of a Lower Cretaceous fluvio-lacustrine sequence of Central Western Argentina. In: ANNUAL MEETING OF THE AMERICAN ASSOCIATION OF STRATIGRAPHIC PALYNOLOGISTS. JOINT MEETING WITH THE CANADIAN ASSOCIATION OF PALINOLOGISTS AND THE NORTH AMERICAN MICROPALEONTOLOGY SECTION, 36, 2003. Program with Abstracts, Ontario, AASP- CAP-NAMS, p. 23.

Prámparo, B.; Ballent, S.; Gallego, O.F. \& Milana, J. P. (in press). Paleontología de la Formación Lagarcito (Cretácico Inferior alto), provincia de San Juan, Argentina. Ameghiniana.

Rohn, R. \& Cavalheiro, M.C.T. 1996. Conchostráceos cretácicos da bacia de Tucano (Bahia) e avaliação do potencial cronoestratigráfico destes crustáceos no Mesozóico do Brasil. In: SIMPÓSIO SOBRE O CRETÁCEO DO BRASIL, 4, 1996. Boletim, Rio Claro, UNESP, p. 157-167. 
Shen, Y.B.; Wang, S.E. \& Chen, P.J. 1982. Arthropoda. In: Xi'an Institute of Geology and Mineral Resouces. (ed.) Palaeontological atlas of northwest China, Shaanxi, Gansu, Ningxia volume, part III, Mesozoic and Cenozoic, Geological Publishing House, p. 53-70.

Shen, Y.B.; Gallego, O.F. \& Martínez, S. 2004. The conchostracan genus Migransia from the Tacuarembó Formation (Late Jurassic - ?Early Cretaceous, Uruguay) with notes on its geological age. Journal of South American Earth Sciences, 16(7):631-638.

Tasch, P. 1987. Fossil Conchostraca of the Southern Hemisphere and Continental Drift.Paleontology, Biostratigraphy and Dispersal. Boulder, Geological Society of America, 290 p. (Memoir 165).
Wang, W. 1987. Mesozoic conchostracans from western Liaoning province, China. In: Yu Xihan; Wang Wuli; Liu Xitin; Zhang Wu; Zheng Shaolin; Zhang Zhicheng; Yu Qingshan; Ma Fengzhen; Dong Gouyi; Yao Peiyi (eds.) Mesozoic Stratigraphy and Palaleontology of western Liaoning, Geological Publishing House, p. 134-201.

Wang, W. 1989. Early Cretaceous conchostracans of northeast China. In: P.J. Chen; K.D Xu \& J.H. Chen (eds.) Selected papers for a symposium on the Cretaceous of South China (Tian Tai), Nanjing University Press, p. 305-310.

Zhang, W.T.; Chen, P.J. \& Shen, Y.B. 1976. Fossil Conchostraca of China. Beijing, Science Press, 325 p.

Received September, 2003, accepted January, 2004. 